\title{
An Inflation Generation
}

\author{
Commencement Address by Lawrence K. Roos, President, Federal Reserve Bank of St. Louis, to the Graduating \\ Class of 1980, Westminster College, Fulton, Missouri, May 18, 1980
}

$\mathrm{T}$ was 34 years ago that Winston Churchill came to Westminster and warned his audience and the nation of an ominous threat to our peace and security by enemies from abroad. The course of world events in the intervening years has fully justified his concern.

Today, I would warn you of a different threat of similar gravity - a threat that, in this instance, comes not from abroad but from within our own society. It is a threat so complex and confusing that, to paraphrase John Maynard Keynes, not one man in a million fully comprehends its true nature. The threat I would warn you of is accelerating inflation - a burden which our nation has endured for the past decade and which, unless appropriate counter-measures are promptly taken, is likely to have catastrophic economic, social, and political consequences in the years to come.

Your graduating class, the Class of 1980 , is part of an inflation generation. You have already been witnesses to and victims of rapidly increasing prices, record-high rates of interest, a marked decline in the value of the dollar on international exchanges, and the many other manifestations of persistent inflation.

The economic environment you have inherited stands in sharp contrast to that which faced my graduating class some 40 years ago. Unlike what you are experiencing, the Class of 1940 was part of a deflation generation. We had grown up during a time of severe unemployment and major economic recession. In sharp contrast to the spiraling price levels of today, prices in 1940 were actually lower than they had been 10 years earlier. I cite this contrast merely to emphasize that, while the nature of the economic malaise facing your class and mine is in a sense quite different, we have both been confronted with circumstances of critical significance to the survival of our economic and political system.

No challenge facing this Class of 1980 is more compelling than that of breaking the momentum of chronic inflation. Unless this is accomplished, there is no hope of restoring to this nation the economic growth and stability necessary for its continued prosperity and security.

The evils of inflation are many. Some are well known; others are well hidden. Perhaps the best un derstood are its economic costs. It was not so long ago that "a penny saved" was actually "a penny earned." That principle - that saving will be rewarded - is vital to economic progress. For without saving, investment (that is, the formation of capital) is not possible. Without capital formation, labor is denied the tools with which to increase the production of goods and services. Unfortunately, however, inflation has severely eroded the incentive to save. A person who placed $\$ 10,000$ in a savings account 15 years ago would by now have accumulated an additional $\$ 8,000$ in compounded interest. After adjusting for the rise in prices over the past 15 years, however, that $\$ 18,000$ is actually worth only about $\$ 8,000$ in "real" value. 
This lesson has not been lost on you, nor has it passed unnoticed by millions of other Americans. As a result, there has been a retreat from savings and the associated investment so essential for growth in productivity. In the past five years alone, the rate of personal saving has fallen from more than 7 percent to $4 \frac{1}{2}$ percent annually. This, in turn, has resulted in diminished growth of investment in industrial plant and equipment and a serious drop in commitments to research and development, both of which underlie industrial productivity. Since the early part of the 1970 s, productivity growth has slowed to about onehalf of its former rate. That rising real income is impossible without rising productivity should come as no surprise to you graduates, most of whom, I have been told, are graduating with degrees in economics and business administration. You know that when the pie ceases to grow larger, the portions must grow smaller. In this case, smaller portions mean a declining standard of living for all of us.

Yet, as bad as the economic effects of inflation are, they are less worrisome than another seldom noticed or, at least, seldom mentioned aspect of the problem: that is, the threat to our personal political freedom posed by inflation - the fact that it can destroy the very foundation of our democratic form of government. Inflation erodes our political system by robbing us, as individuals, of the opportunity to approve or disapprove the most basic of government decisions - those of money creation and taxation. Inflation permits government to finance its expenditures in a manner that hides its actions from the scrutiny of its citizens.

Government expenditures, traditionally, have been financed either by taxes levied by Congress or by borrowing from the private sector to finance deficits. These methods have the advantage of forcing Congress to establish, in plain sight of the electorate, a level of spending and to support that spending through direct taxation or borrowing. Citizens are given the opportunity to approve or disapprove of the government's actions at the polls. This is the traditional manner by which elected officials are held accountable for their actions.

In recent years, however, a practice of "backdoor" financing has evolved which enables government to circumvent its traditional accountability. In the past two decades, the federal government, instead of supporting its expenditures by taxation, has come to rely more and more on deficit spending to finance its operations. Now deficit spending, by itself, is not necessarily inflationary, if deficits are financed solely by increased borrowing in private markets. However, higher interest rates, which are a by-product of government borrowing in private markets, are not popular choices for elected officials. So instead of "facing the music" of increased taxes or higher interest rates, fiscal policymakers have made use of the technique of "hidden financing" - hidden, that is, from the voters.

When it resorts to hidden financing, the government creates money through the monetization or pur. chase of its debt by the Federal Reserve. When the Fed monetizes federal deficits, it increases commercial bank reserves and thereby expands the supply of money available for spending. Increases in the money supply lead to accelerated inflation, reducing the purchasing power of individuals as assuredly as if taxes had been increased in the first place. In fact, taxes have been increased for inflation is a tax. It is a tax that is neither subject to voter approval nor directly associated with voter-approved government spending decisions. Our founding fathers would have called such an arrangement "taxation without representation" and, indeed, it is truly that.

Hidden financing has enabled the government to expand its role substantially without a specific mandate from the electorate. Whereas in 1940 federal government expenditures amounted to $13.5 \%$ of the gross national product, last year they consumed $21 \%$ of the resources of the economy. When you include welfare, social security, and debt service costs, the government's share of economic consumption has grown from one-sixth of the total economy in 1940 to one-third today. Would this great expansion in the size of government have occurred had the American people been given the opportunity explicitly to decide the issue at the polls? I doubt it!

In view of the serious nature of the economic and political consequences of inflation, I would be remiss if I did not suggest a workable way of alleviating the problem.

Clearly, inflation is not a self-generating and uncontrollable phenomenon. It occurs only when money growth outstrips the growth of production of goods and services. It can be diminished in one of two ways: either by increasing production or by slowing the rate of money growth. Both of these alternatives merit consideration.

Unfortunately, almost all available options for increasing productivity involve long-range actions and long-run responses. Tax reforms, for example, would increase incentives to save and invest, and thereby increase productivity. A lessening of government regulation would tend to lessen costs of production and 
increase output. Reductions in the size of government would free resources for use by the private sector and thereby increase the output of goods and services demanded by consumers. However, all of these are changes of an institutional nature that entail legislative actions as well as a fundamental reordering of expressed national priorities. While highly desirable, it would be unrealistic to believe that they could be brought to fruition quickly enough to have a demonstrable early effect on inflation.

A reduction in the rate of money growth, on the other hand, offers a means of reducing inflation fairly quickly. The Federal Reserve, through its open market operations, can increase or decrease bank reserves almost instantaneously and thereby can quickly expand or contract the amount of spendable money in the hands of the public. By gradually reducing the growth of the money supply, the Fed can bring down inflation over a predictable and reasonably short period of time. In this connection, I would point out that there is no responsible way to reduce the basic rate of inflation instantaneously. To seek an immediate solution by drastically slamming on the money growth brakes would have a shocking effect on the economy in terms of lost output and high unemployment. It would create intolerable conditions of recession which in turn would bring forth pressures for inflationary actions to spend our way out of our distress. However, a gradual reduction in the growth of the money supply, say at a rate of 1 or $2 \%$ per year, would exert minimal economic stress and would significantly rem duce inflation within a few years.

Although such a policy has been the stated object of the Federal Reserve System for almost a decade, the manner in which the policy was implemented in the past tended to frustrate the Fed's good intentions. Prior to October 6, 1979, the Fed had two incompatible monetary policy goals: the reduction of money growth and the stabilization of interest rates in the short run. The simultaneous achievement of these two objectives was frequently impossible. Whenever money growth targets were incompatible with interest rate targets, the objective of money growth control was abandoned in favor of short-run interest rate stabilization. This not only contributed to rising inflation, but caused the Federal Reserve to lose credibility in the eyes of the public as its record of performance failed to measure up to its stated objectives.

Fortunately, this has changed. There is now solid reason for optimism that monetary policymaking has finally turned the corner and will be a more successful tool in coping with inflation than in the past.
Last October, the Federal Reserve announced new operating procedures which, in effect, eliminate the previous dilemma of concurrently setting interest rate and monetary growth targets. Stabilization of interest rates, in the short run, has been abandoned as a tool of policy, and the goal of reducing money growth has been reaffirmed. What is even more heartening is that evidence to date indicates that the Fed will be successful in achieving its money growth targets. Money growth has been substantially reduced from the inflation-generating levels of the pre-October period. If this trend is continued, there is ample reason to believe that we will experience reduced inflation in the months and years ahead. Interest rates have been permitted to fluctuate freely. Furthermore, the initial dramatic interest rate increases, which were attributable to early doubts about the Fed's ability to achieve its announced goals, have been reversed. As more people become convinced that the rate of growth of money is indeed being controlled and will continue to be reduced, inflationary expectations will recede and interest rates will continue to decline.

If one were to describe the current state of monetary policy-making in terms that the late Winston Churchill might have used, it could be said that "the tide of battle is turning, but the day is not yet won." Significant economic, intellectual, and political barriers must still be overcome before the public can feel truly confident that the Fed's new procedures will be permitted to be carried through to fruition. Interest rates, although easing, are still at relatively high levels, and important parts of the economy such as housing, farming, and other interest-sensitive activities are feeling the effects of credit restraint. Continued restraint will mean a period of softness in the economy, and individuals who are adversely affected can be expected to call vociferously for a return to a more stimulative monetary policy. Moreover, many disciples of interest rate stabilization find it difficult to accept control of money and credit as a legitimate basis for the implementation of monetary policy. Finally, 1980 is an election year, and the bitter medicine of monetary restraint has never been welcomed by candidates for public office. Pressures such as these will undoubtedly continue to test the resolve of policymakers to persist in their efforts to eliminate inflation.

Whether or not yours will continue to be an inflation generation depends directly on our ability, collectively, to resist the pressures of those who, unwilling to tolerate the pain of the moment, will call for a return to the expansive policies that created the current inflation. In their desire for relief in the short run, they would have us believe that a little inflation 
is not so bad, that we can adjust to it and learn to tolerate it.

This is simply not true. There is no hope for a persistent "little inflation." Wherever nations have ac cepted inflation as a way of life, they have discovered that today's $10 \%$ inflation becomes tomorrow's $12 \%$, the next year's $15 \%$ inflation, and so on.

This trend need not continue here, if we have the discipline to accept a certain amount of temporary pain for the promise of better circumstances in the future. While yours is presently an inflation generation, it need not remain so. Indeed, it must not remain so.
I have described the devastating consequences of a continuation of accelerating inflation, and I have offered what $I$ believe to be a practical and workable way to eliminate the problem. It is up to you as thinking men and women to take the lead in standing for what is in the best interests of the free society of which you are a part. Your generation has a clear choice. It can go down in history as one which tolerated inflation and thus gave witness to the decline of America as a great economic power, or it can leave its mark as the generation which eliminated inflation and restored the foundation of stability and growth so necessary to our national survival. I have full confidence that you will make the proper choice.

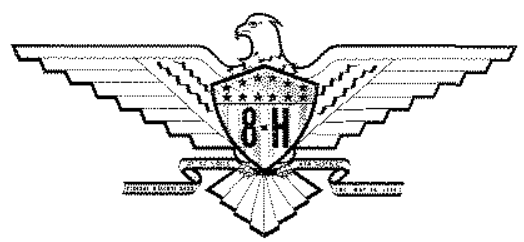

